\title{
Pengetahuan Ibu Hamil Tentang Pencegahan Covid-19
}

\author{
Lubna Tahta Lazuardi El Rahman ${ }^{1 *}$, Yuni Uswatun Khasanah ${ }^{2 *}$, Anggit Eka Ratnawati ${ }^{*}$ \\ 1, 2, 3 Politeknik Kesehatan Ummi Khasanah, Yogyakarta, Indonesia \\ *lubnatahtael@gmail.com, yunifindra@yahoo.co.id, anggiteka253@yahoo.com
}

\section{ARTICLE INFO}

Article history:

Received November 23,2021

Accepted December 15, 2021

Published January 25, 2022

\section{Kata Kunci:}

Tingkat Pengetahuan Pencegahan Covid 19 Ibu Hamil

Key words:

Pregnant Women Knowledge Level Covid-19 Prevention

DOI:

https://10.48092/jik.v8i1.158

\section{ABSTRAK}

Latar Belakang: Menurut data dari Perkumpulan Obstetri dan Ginekologi Indonesia (POGI) Jakarta, didapatkan jumlah ibu hamil yang terinfeksi COVID-19 sejumlah 13,7\% ibu hamil. Hal ini dikarenakan wanita hamil memiliki riwayat perjalanan atau tinggal di wilayah transmisi lokal, riwayat kontak dengan kasus konfirmasi, dan riwayat kontak dengan hewan yang terinfeksi COVID Metode: Desain yang digunakan adalah deskriptif kuantitatif dengan pendekatan cross sectional. Populasi dalam penelitian ini adalah seluruh ibu hamil yang periksa di PMB Sumarni Pundong Bantul sebanyak 30 responden. Pengambilan data menggunakan kuesioner sebanyak 27 kuesioner yaitu 5 soal dari uji validitas dan 22 soal menggunakan kuesioner yang diadopsi dari penelitian Yanti, dkk (2020), sedangkan analisa menggunakan analisa univariat. Hasil: Hasil penelitian ini menunjukkan bahwa mayoritas responden berusia 20-35 tahun sebanyak 27 responden (90\%), berpendidikan SMA sebanyak 16 reponden (53\%), Bekerja sebanyak 19 responden $(63,3 \%)$, Multipara sebanyak 18 responden $(60 \%)$, trimester 3 sebanyak 18 responden $(60 \%)$ responden berpengetahuan baik sebanyak 22 responden $(73,3 \%)$, dan pengetahuan cukup sebanyak 8 responden (26,7\%). Kesimpulan: Pengetahuan ibu Hamil di PMB Sumarni Pundong Bantul Yogyakarta tahun 2021 adalah Baik.

\section{ABSTRACT \\ Knowledge of Pregnant Women on Covid-19 Prevention}

Background: According to data from the Indonesian Obstetrics and Gynecology Association (POGI) Jakarta, it was found that the number of pregnant women infected with COVID-19 was $13.7 \%$ of pregnant women. This is because pregnant women have a history of traveling or living in local transmission areas, a history of contact with confirmed cases, and a history of contact with animals infected with COVID. Methods: The design used is descriptive quantitative with a cross sectional approach. The population in this study were all pregnant women who were examined at PMB Sumarni Pundong Bantul as many as 30 respondents. Data collection using a questionnaire as many as 27 questionnaires, namely 5 questions from the validity test and 22 questions using a questionnaire adopted from the research of Yanti, et al (2020), while the analysis uses univariate analysis. Results: The results of this study indicate that the majority of respondents aged 20-35 years as many as 27 respondents (90\%), high school education as many as 16 respondents (53\%), working as many as 19 respondents (63.3\%), Multipara as many as 18 respondents (60\%), third trimester as many as 18 respondents (60\%) respondents with good knowledge as many as 22 respondents (73.3\%), and sufficient knowledge as many as 8 respondents (26.7\%). Conclusion: Knowledge of pregnant women at PMB Sumarni Pundong Bantul Yogyakarta in 2021 is good.

Thisopenaccessarticleisunderthe CC-BY-SAlicense. 


\section{PENDAHULUAN}

Angka kematian ibu di Indonesia pada tahun 2019 menunjukan angka 205 kematian per 100.000 kelahiran hidup. Dari 4221 kasus di tahun 2018-2019, penyebab kematian ibu terbanyak adalah perdarahan dengan 1.280 kasus, hipertensi dalam kehamilan sebanyak 1.066 kasus, dan infeksi sebanyak 207 kasus. (KEMENKES RI, 2020). Tingkat kematian yang cenderung tinggi ini membuat kita harus semakin waspada dengan perkembangan kondisi. Salah satunya Indonesia yang sedang dihadapkan dengan pandemi global Corona Virus Disease (COVID-19) sejak awal tahun 2020 (WHO, 2020).

COVID-19 adalah gangguan sistem pernafasan akut yang disebabkan oleh Virus Severe Acute Respiratory Syndrome Coronavirus 2 (SARSCov-2) yang terjadi pertama kali di Wuhan, Provinsi Hubei, Tiongkok pada Desember 2019 dan dengan cepat virus ini tersebar keseluruh dunia (Lu, Stratton, Tang, 2020). Menurut data dari Perkumpulan Obstetri dan Ginekologi Indonesia (POGI) Jakarta, didapatkan data $13,7 \%$ wanita hamil lebih mudah terinfeksi virus COVID-19 dibandingkan mereka yang tidak hamil (Rohmah \& Nurdianto, 2020). Faktor-faktor yang mempermudah wanita hamil terinfeksi SARS-COV-2 yaitu memiliki riwayat perjalanan atau tinggal di negara atau wilayah Indonesia yang merupakan transmisi lokal, riwayat kontak dengan kasus konfirmasi atau probable terinfeksi SARS-COV-2 dan riwayat kontak dengan hewan yang terinfeksi SARS-COV-2 (KEMENKES RI, 2020).

Menurut Anugrah Wiendyasaari selaku Kasi Kesehatan Keluarga dan Gizi Dinas Kesehatan Kabupaten Bantul, sejak awal tahun terjadi sembilan kematian ibu hamil yang enam diantaranya terjadi selama pandemi. Sebagian besar kematian ibu hamil disertai dengan penyakit bawaan, dua diantaranya meninggal mendadak sebelum sempat dilakukan pemeriksaan klinis, dan satu kematian ibu hamil yang merupakan PDP (Pasien Dalam Pemantauan) COVID19 (Suara Jogja, 2020).

Angka fatalitas kasus infeksi SARS-COV-2 atau COVID-19 pada wanita hamil mencapai $25 \%$. Dampak lanjut dari infeksi COVID-19 pada ibu hamil yakni munculnya kekhawatiran terkait pertumbuhan dan perkembangan janinnya. Oleh karena itu ibu hamil memerlukan perhatian khusus terkait pencegahan, diagnosis dan penatalaksanaan (Poon et al, 2020). Urgensi yang cukup tinggi menyebabkan diperlukannya studi lebih lanjut terkait Pengetahuan Ibu Hamil tentang Pencegahan COVID-19 untuk ditindaklanjuti sebagai salah upaya pencegahan penyebarluasan COVID-19 di kalangan ibu hamil di
PMB Sumarni Pundong Bantul Yogyakarta Tahun 2021.

\section{METODE}

Penelitian ini merupakan penelitian deskriptif kuantitatif. Metode pendekatan yang digunakan cross sectional. Penelitian ini dilakukan di PMB Sumarni Pundong Bantul, Yogyakarta pada bulan Januari hingga September 2021. Penelitian ini telah mendapat izin dari PMB Bidan Sumarni Pundong, Bantul, Yogyakarta melalui surat izin dari Politeknik Kesehatan Ummi Khasanah Bantul Yogyakarta. Populasi dalam penelitian ini berjumlah 55 ibu hamil. Cara menentukan sampel dilakukan secara accidental sampling dengan kriteria inklusi dan eksklusi, didapatkan sebanyak 30 responden.

Instrumen penelitian yang digunakan berupa kuesioner yang didapatkan dari hasil uji validitas dan uji reliabilitas, dan dari kuesioner baku dari Jurnal Keperawatan Jiwa Volume 8 No. 3 yang ditulis oleh Yanti, dkk (2020) dengan judul Gambaran Pengetahuan Masyarakat tentang COVID-19 dan Perilaku Masyarakat di Masa Pandemi COVID-19 dengan pertanyaan sesuai judul penelitian dan indikator penelitian. Analisis data yang digunakan dalam penelitian ini adalah analisis univariat.

\section{HASIL DAN PEMBAHASAN}

\section{Karakteristik Responden}

Tabel 1. Distribusi Frekuensi Karakteristik Responden

\begin{tabular}{|c|c|c|c|}
\hline $\mathrm{No}$ & Karakteristik & Frekuensi (f) & Persentase (\%) \\
\hline \multirow[t]{4}{*}{1.} & \multicolumn{3}{|l|}{ Usia Ibu } \\
\hline & 1) 20-35 tahun & 27 & $90 \%$ \\
\hline & 2) >35 tahun & 3 & $10 \%$ \\
\hline & Total & 30 & $100 \%$ \\
\hline \multirow[t]{6}{*}{2.} & \multicolumn{3}{|l|}{ Pendidikan } \\
\hline & 1) $\mathrm{SD}$ & 1 & $3,3 \%$ \\
\hline & SMP & 6 & $20 \%$ \\
\hline & SMA & 16 & $53 \%$ \\
\hline & PT & 7 & $23,3 \%$ \\
\hline & Total & 30 & $100 \%$ \\
\hline \multirow[t]{4}{*}{3.} & \multicolumn{3}{|l|}{ Pekerjaan } \\
\hline & 1) Tidak Bekerja & 11 & $36,7 \%$ \\
\hline & Bekerja & 19 & $63,3 \%$ \\
\hline & Total & 30 & $100 \%$ \\
\hline \multirow[t]{4}{*}{4.} & \multicolumn{3}{|l|}{ Paritas Ibu } \\
\hline & 1) Primipara & 12 & $40 \%$ \\
\hline & 2) Multipara & 18 & $60 \%$ \\
\hline & Total & 30 & $100 \%$ \\
\hline \multirow[t]{5}{*}{5.} & \multicolumn{3}{|l|}{ Umur Kehamilan } \\
\hline & 1) Trimester 1 & 3 & $10 \%$ \\
\hline & Trimester 2 & 9 & $30 \%$ \\
\hline & Trimester 3 & 18 & $60 \%$ \\
\hline & Total & 30 & $100 \%$ \\
\hline
\end{tabular}


Berdasarkan data hasil penelitian distribusi frekuensi diketahui bahwa mayoritas responden berusia 20-35 tahun yaitu sebanyak 27 responden (90\%), berdasarkan pendidikan diketahui bahwa mayoritas responden memiliki tingkat pendidikan SMA sebanyak 16 responden $(53 \%)$, berdasarkan pekerjaan diketahui bahwa mayoritas responden bekerja sebanyak 19 responden $(63,3 \%)$, kemudian dilihat dari jumlah anak atau paritas yaitu mayoritas responden multipara 18 responden $(60 \%)$. Dan berdasarkan usia kehamilan responden mayoritas responden memasuki umur kehamilan trimester tiga yaitu sebanyak 18 responden $(60 \%)$.

Berdasarkan hasil penelitian yang terdapat pada tabel 1 diketahui bahwa mayoritas responden berusia antara 20-35 tahun sebanyak 27 responden (90\%). Tingkat pengetahuan terbanyak dimiliki oleh responden dengan rentang usia 20-35 tahun sebanyak 20 responden $(66,7 \%)$ dengan tingkat pengetahuan baik.

Usia mempengaruhi daya tangkap dan pola pikir seseorang. Dengan bertambahnya usia seseorang menyebabkan semakin berkembangnya daya tangkap dan pola pikirnya sehingga pengetahuan yang didapat semakin meningkat juga (Aulia, 2013).

Hasil penelitian ini sesuai dengan penelitian sebelumnya yang dilakukan oleh Wulandari (2014) yang menyatakan bahwa usia yang cukup akan mempengaruhi tingkat kematangan dan kekuatan seseorang akan lebih matang dalam berfikir dan bekerja. Dari segi kepercayaan masyarakat seseorang yang lebih dewasa dipercaya dari orang yang belum tinggi kedewasaannya. Hal disebabkan meningkatnya usia akan meningkat pula pengalaman dan kematangan jiwa. Jadi semakin meningkat usia seseorang maka dimungkinkan akan semakin banyak pula pengalaman yang didapat dan banyaknya pengalaman akan meningkatkan tingkat pengetahuan.

Mayoritas tingkat pendidikan responden adalah SMA sebanyak 16 responden (53\%). Berdasarkan pendidikan didapatkan 11 responden $(36,7 \%)$ mempunyai tingkat pengetahuan baik dan 5 responden $(16,7 \%)$ mempunyai tingkat pengetahuan cukup.

Pendidikan adalah proses perubahan sikap dan perilaku seseorang atau kelompok dan merupakan usaha mendewasakan manusia melalui upaya pengajaran dan pelatihan (Budiman \& Riyanto, 2013). Semakin tinggi pendidikan seseorang maka semakin cepat menerima dan memahami suatu informasi sehingga pengetahuan yang dimiliki juga semakin tinggi (Sriningsih, 2011). Hal ini dapat disimpulkan bahwa dengan tingginya pendidikan akan semakin mudah seseorang untuk menggali informasi. Hal ini sesuai dengan penelitian sebelumnya yang dilakukan oleh Maramis, dkk (2013) yang mengatakan bahwa pendidikan berbanding lurus dengan dengan tingkat pemahaman terhadap suatu informasi, yang artinya semakin tinggi tingkat pendidikan seseorang maka semakin tinggi juga tingkat pengetahuan seseorang dan ketepatan dalam bersikap dan berperilaku, maka pendidikan memiliki pengaruh yang besar pada aspek pikiran, sikap, kemauan, dan tindakan.

Mayoritas responden adalah sebagai ibu yang bekerja yaitu sebanyak 19 responden (63,3\%). Berdasarkan pekerjaan yang mempunyai tingkat pengetahuan baik sebanyak 14 responden $(46,7 \%)$ dan yang mempunyai tingkat pengetahuan cukup sebanyak 5 responden $(16,7 \%)$

Lingkungan pekerjaan mempengaruhi proses masuknya pengetahuan ke dalam individu karena adanya interaksi timbal balik ataupun tidak yang akan direspon sebagai pengetahuan oleh individu. Lingkungan pekerjaan yang baik akan pengetahuan yang didapatkan akan baik tapi jika lingkungan kurang baik maka pengetahuan yang didapat juga akan kurang baik. Hal ini sesuai dengan yang dikatakan oleh Dharmawati dan Wirata (2016) yang menyatakan bahwa tingkat pendidikan pada dasarnya adalah salah satu faktor yang mempengaruhi pengetahuan dan tindakan seseorang karena pengetahuan akan langsung berpengaruh pada perilaku.

Mayoritas responden sebanyak 18 responden $(60 \%)$ multipara yang mempunyai tingkat pengetahuan baik sebanyak 14 responden $(46,7 \%)$ dan yang mempunyai pengetahuan cukup sebanyak 4 responden $(13,3 \%)$

Hasil penelitian ini sejalan dengan penelitian sebelumnya yang dilakukan oleh Wulandari (2014) yang mengatakan bahwa seorang ibu yang memiliki riwayat kehamilan lebih banyak dipastikan memiliki pengalaman lebih tinggi dibandingkan oleh ibu yang baru pertama hamil atau baru pertama memiliki anak. Hal ini menyangkut dari pengalaman seseorang dari banyaknya kehamilan yang dialami dan permasalahannya sehingga lebih banyak ibu mengalami kehamilan semakin tinggi pula pengalaman dalam menghadapi berbagai permasalahan saat proses kehamilannya.

Mayoritas responden sebanyak 18 responden $(60 \%)$ saat ini memasuki umur kehamilan trimester tiga yang mempunyai tingkat pengetahuan baik sebanyak 12 responden $(40 \%)$ dan yang mempunyai pengetahuan cukup sebanyak 6 responden $(20 \%)$.

Periode kehamilan yang dihitung sejak hari pertama haid terakhir (HPHT) hingga dimulai persalinan sejati, yang menandai awalnya periode antepartum. Periode antepartum dibagi menjadi tiga trimester yang masing-masing terdiri dari 13 minggu 
atau tiga bulan menurut hitungan kalender. Pembagian waktu ini diambil dari ketentuan yang mempertimbangkan bahwa lama kehamilan dikperkirakan kurang lebih 280 hari, 40 minggu, sepuluh bulan (berdasarkan perputaran bulan atau lunar) atau sembilan bulan sejak hari pertama haid terakhir (dengan perkiraan siklus 28 hari). Hal ini membuat kehamilan berlangsung kurang lebih 266 hari atau 38 minggu (Fahira\& Arifuddin, 2017)

Hal ini sejalan dengan penelitian saya bahwa umur kehamilan mempengaruhi pengetahuan. Hal ini dikarenakan semakin bertambahnya umur kehamilan maka pengetahuan yang dimiliki ibu semakin baik. Hal ini dapat dibuktikan dengan ibu sudah berhasil melewati beberapa periode kehamilan yang dimulai dari trimester I.

\section{Tingkat Pengetahuan}

Tabel 2. Distribusi Frekuensi Tingkat Pengetahuan

\begin{tabular}{llcc}
\hline No & $\begin{array}{c}\text { Tingkat } \\
\text { Pengetahuan }\end{array}$ & $\begin{array}{c}\text { Frekuensi } \\
\text { (f) }\end{array}$ & Persentase (\%) \\
\hline 1. & Baik & 22 & $73,3 \%$ \\
2. & Cukup & 8 & $26,7 \%$ \\
& Total & 30 & $100 \%$ \\
\hline
\end{tabular}

Mayoritas responden mempunyai tingkat pengetahuan baik yaitu sebanyak 22 responden $(73,3 \%)$.

Tabel 3. Crostabulasi Karakteristik dan Tingkat Pengetahuan

\begin{tabular}{|c|c|c|c|c|c|c|c|}
\hline \multirow[t]{3}{*}{ No } & \multirow[t]{3}{*}{ Karakteristik } & \multicolumn{4}{|c|}{ Tingkat Pengetahuan } & \multicolumn{2}{|c|}{ Total } \\
\hline & & \multicolumn{2}{|c|}{ Baik } & \multicolumn{2}{|c|}{ Cukup } & \multirow[b]{2}{*}{$\mathrm{F}$} & \multirow[b]{2}{*}{$\%$} \\
\hline & & $\mathrm{F}$ & $\%$ & $\mathrm{~F}$ & $\%$ & & \\
\hline \multirow[t]{4}{*}{1.} & Usia Ibu & & & & & & \\
\hline & 1) 20-35 tahun & 20 & $66,7 \%$ & 7 & $23,3 \%$ & 27 & $90 \%$ \\
\hline & 2) $>35$ tahun & 2 & $6,7 \%$ & 1 & $3,3 \%$ & 3 & $10 \%$ \\
\hline & Total & 22 & $73,3 \%$ & 8 & $26,7 \%$ & 30 & $100 \%$ \\
\hline \multirow[t]{6}{*}{2.} & Pendidikan & & & & & & \\
\hline & 1) $\mathrm{SD}$ & 1 & $3,3 \%$ & 0 & $0 \%$ & 1 & $3,3 \%$ \\
\hline & 2) SMP & 4 & $13,3 \%$ & 2 & $6,7 \%$ & 6 & $20 \%$ \\
\hline & 3) SMA & 11 & $36,7 \%$ & 5 & $16,7 \%$ & 16 & $53,3 \%$ \\
\hline & 4) $\mathrm{PT}$ & 6 & $20 \%$ & 1 & $3,3 \%$ & 7 & $23,3 \%$ \\
\hline & Total & 22 & $73,3 \%$ & 8 & $26,7 \%$ & 30 & $100 \%$ \\
\hline \multirow[t]{4}{*}{3.} & Pekerjaan & & & & & & \\
\hline & 1) Tidak & 8 & $26,7 \%$ & 3 & $10 \%$ & 11 & $36,7 \%$ \\
\hline & Bekerja & 14 & $46,7 \%$ & 5 & $16,7 \%$ & 19 & $63,3 \%$ \\
\hline & $\begin{array}{l}\text { 2) Bekerja } \\
\text { Total }\end{array}$ & 22 & $73,3 \%$ & 8 & $26,7 \%$ & 30 & $100 \%$ \\
\hline \multirow[t]{4}{*}{4.} & Paritas Ibu & & & & & & \\
\hline & 1) Primipara & 8 & $26,7 \%$ & 4 & $13,3 \%$ & 15 & $50 \%$ \\
\hline & 2) Multipara & 14 & $46,7 \%$ & 4 & $13,3 \%$ & 15 & $50 \%$ \\
\hline & Total & 22 & $73,3 \%$ & 8 & $26,7 \%$ & 30 & $100 \%$ \\
\hline \multirow[t]{5}{*}{5.} & $\begin{array}{l}\text { Umur } \\
\text { Kehamilan }\end{array}$ & & & & & & \\
\hline & 1) Trimester 1 & 2 & $6,7 \%$ & 1 & $3,3 \%$ & 3 & $10 \%$ \\
\hline & 2) Trimester 2 & 8 & $26,7 \%$ & 1 & $3,3 \%$ & 9 & $30 \%$ \\
\hline & 3) Trimester 3 & 12 & $40 \%$ & 6 & $20 \%$ & 18 & $60 \%$ \\
\hline & Total & 22 & $73,3 \%$ & 8 & $26,7 \%$ & 30 & $100 \%$ \\
\hline
\end{tabular}

Mayoritas responden berusia 20-35 tahun mempunyai tingkat pengetahuan yang baik yaitu sebanyak 20 responden $(66,7 \%)$, dari segi pendidikan mayoritas responden berpendidikan SMA memiliki pengetahuan yang baik yaitu 11 responden $(36,7 \%)$, dari segi pekerjaan mayoritas responden yang bekerja memiliki pengetahuan yang baik yaitu 14 responden $(46,7 \%)$, dari segi jumlah anak atau paritas tingkat pengetahuan ibu baik sebanyak 14 responden $(46,7 \%)$. Dan dari segi umur kehamilan mayoritas responden memasuki umur kehamilan trimester tiga mempunyai pengetahuan yang baik yaitu sebanyak 12 responden $(40 \%)$.

Responden yang memiliki pengetahuan baik sebanyak 22 responden $(73,3 \%)$ dan responden dengan tingkat pengetahuan cukup sebanyak 8 responden $(26,7 \%)$. Dari segi umur mayoritas responden berusia 20-35 tahun yang mempunyai tingkat pengetahuan baik sebanyak 20 responden $(66,7 \%)$, dari segi pendidikan mayoritas responden berpendidikan SMA mempunyai tingkat pengetahuan baik sebanyak 11 responden $(36,7 \%)$, dari segi pekerjaan mayoritas responden yang bekerja mempunyai pengetahuan yang baik sebanyak 14 responden $(46,7 \%)$, dari segi paritas mayoritas dari jumlah responden multipara yaitu memiliki pengetahuan baik sebanyak 14 reponden $(46,7 \%)$.

Tingkat pengetahuan baik dikarenakan mayoritas responden berusia 20-35 tahun. Hal ini berkaitan dengan usia seseorang Usia mempengaruhi daya tangkap dan pola pikir seseorang. Dengan bertambahnya usia seseorang menyebabkan semakin berkembangnya daya tangkap dan pola pikirnya sehingga pengetahuan yang didapat semakin meningkat juga (Aulia, 2013). Hal ini sejalan dengan penelitian Budiman \& Riyanto (2013) yang mengatakan bahwa usia seseorang mempengaruhi pola pikir dan daya tangkap dalam mempelajari suatu objek. Semakin bertambahnya usia maka semakin bertambah pula pola pikir dan daya tangkapnya untuk mempelajari sesuatu sehingga pengetahuan yang didapatpun semakin baik.

\section{KESIMPULAN DAN REKOMENDASI}

Mayoritas responden berusia 20-35 tahun dengan mayoritas pendidikan SMA. Mayoritas responden sebagai ibu yang bekerja, mayoritas responden adalah multipara, mayoritas responden adalah ibu hamil yang memasuki trimester tiga, mayoritas responden memiliki tingkat pengetahuan yang baik. Saran untuk penyedia pelayanan kesehatan terutama PMB adalah agar PMB dapat lebih menerapkan protokol kesehatan untuk mencegah penularan COVID-19 untuk ibu hamil yang melakukan 
pemeriksaan. Saran untuk penelitian selanjutnya yaitu dapat menambah variabel lain untuk diteliti seperti lingkungan dan sosial budaya karena hal tersebut bisa mempengaruhi pengetahuan responden.

\section{REFERENSI}

Aulia, R., 2013. Analisis Pengetahuan dan Perilaku Masyarakat Terhadap Kualitas Fisik (Kekeruhan, Bau, Rasa) dan Bakteriologis (Coliform) Air Sumur Gali (Studi di Desa Arjasa, Kecamatan Arjasa, Kabupaten Jember).

Budiman \& Riyanto, A., 2013. Kapita Selekta Kuesioner Pengetahuan dan Sikap dalam Penelitian Kesehatan. Jakarta: Salemba Medika.

Dharmawati, I. G. A. A. \& Wirata, I. N., 2016. Hubungan Tingkat Pendidikan, Umur, dan Masa Kerja dengan Tingkat Pengetahuan Kesehatan Gigi dan Mulut pada Guru Penjaskes SD di Kecamatan Tampak Siring Gianyar. Jurnal Kesehatan Gigi Vol. 4 No.1.

Fahira, N. \& Arifuddin, A., 2017. Faktor Risiko Kejadian Preeklamsia pada Ibu Hamil di RSU Anutapura Kota Palu. Jurnal Kesehatan Tadulako.

Kementerian Kesehatan Republik Indonesia, 2020. Profil Kesehatan Indonesia 2019. Jakarta: Keputusan Menteri Kesehatan Republik Indonesia.

Lu, H., Stratton, C. W. \& Tang, Y.-W., 2020. Outbreak of Pneumonia of Unknown Etiology in Wuhan, China: The Mystery and the Miracle.

[Online]

Available at:

https://doi.org/10.1002/jmv.25678

Maramis, R. K., Citraningtyas, G. \& Wehantouw, F., 2013. Analisis Kafein dalam Kopi Bubuk di Kota Manado Menggunakan Spektrofotometri UV-Vis. Pharmacom Jurnal Ilmiah Farmasi.

Poon, L. C. et al., 2020. Global Interim Guidance on Coronavirus Disease 2019 (COVID-19) during Pregnancy and Puerperium from FIGO and Allied Partners: Information for Healthcare Professionals. International Journal of Gynecology \& Obstetrics.

Rohmah, M. K. \& Nurdianto, A. R., 2020. Corona Virus Disease 2019 (COVID-19) pada Wanita Hamil dan Bayi: Sebuah Tinjauan Literatur. Medica Hospitalia.
Sriningsih, I., 2011. Faktor Demografi, Pengetahuan Ibu tentang Air Susu Ibu dan Pemberian ASI Ekslusif. Jurnal Kesehatan Masyarakat.

WHO, 2020. Coronavirus. [Online] Available at: https://www.who.int/healthtopics/coronavirus

Wijana, E. P. E. \& Maulina, M. R., 2020. Arkadia

Digital Media. [Online]

Available at:

https://jogja.suara.com/read/2020/05/14/22 0000/di-bantul-6-ibu-hamil-meninggalselama-pandemi-corona

Wulandari, R., 2014. Hubungan Tingkat Pendidikan Ibu Hamil Dengan Pengetahuan Tanda Bahaya Kehamilan Pada Trimester III Di RB Harapan Bunda Surakarta: STIK PKU Muhammadiyah.

Yanti, N. P. E. D. et al., 2020. Gambaran Pengetahuan Masyarakat tentang COVID-19 dan Perilaku Masyarakat di Masa Pandemi COVID-19. Jurnal Keperawatan Jiwa Volume 3 No.8. 